\title{
WPŁYW INSTYTUCJI LOKALNYCH NA KSZTAŁTOWANIE SIĘ PRZEDSIĘBIORCZOŚCI
}

\section{Streszczenie}

Cel - Celem niniejszego opracowania było poznanie wpływu instytucji, związanych z lokalnym środowiskiem, na kształtowanie się przedsiębiorczości w społeczeństwie.

Metodyka badania - Realizacja założonego celu została osiągnięta dzięki krytycznej analizie literatury oraz sformułowaniu wniosków z przeprowadzonych badań własnych.

Wynik - Analiza ankiet przeprowadzonych wśród przedsiębiorców pozwoliła uzyskać odpowiedzi na pytania, jaki wpływ mają instytucje na kształtowanie się przedsiębiorczości, jak również, jakie jest ich oddziaływanie na efekty osiągane przez przedsiębiorstwa.

Oryginalność/wartość - Wartość dodaną pracy stanowi przeprowadzenie badania na terenie Polski, które wskazało małą istotność oddziaływania instytucji lokalnych na: przedsiębiorczość, przedsiębiorców oraz prowadzone przez nich działalności gospodarcze.

Słowa kluczowe: przedsiębiorczość, uwarunkowania przedsiębiorczości, determinanty przedsiębiorczości, instytucje

\section{THE INFLUENCE OF LOCAL INSTITUTIONS ON THE DEVELOPMENT OF ENTREPRENEURIAL ATTITUDES}

\section{Summary}

Goal - The goal of this paper is attempt to investigate the impact of a local institution on shaping entrepreneurial attitudes in society.

Research methodology - Preparation of the article it required a literature analysis of the subject and drawing conclusions from own research.

Score - As a result of the analysis of the conducted study, it is possible to indicate what impact institutions have on the shaping of entrepreneurial attitudes and what is the impact on the results achieved by enterprises.

Originality /value - The added value of the work is to conduct a study in Poland, which indicates the small significance of the impact of local institutions on the emergence of entrepreneurial attitudes, entrepreneurs and their economic activities.

Key words: entrepreneurship, conditions of entrepreneurship, determinants of entrepreneurship, institutions

DOI: 10.15290/wpewbmn3.2019.09 


\section{Wprowadzenie}

Przedsiębiorczość jest istotnym czynnikiem warunkującym rozwój gospodarczy każdego państwa i regionu. Zatem w interesie państwa jest popularyzacja i propagowanie przedsiębiorczości. Państwo posiada wiele instrumentów, za pomocą których może wpływać na pobudzenie rozwoju przedsiębiorczości. Jednym $\mathrm{z}$ nich są sprawnie funkcjonujące instytucje, które stymulują podmioty gospodarcze dzięki odpowiednio ukierunkowanym bodźcom. Duże możliwości wsparcia, a także oddziaływania na przedsiębiorczość mają jednostki samorządu terytorialnego ${ }^{1}$. Przedsiębiorczość wymaga pobudzenia oraz stworzenia przyjaznych warunków do tego, aby pojawiła się wola prowadzenia własnej firmy. Przed takim zadaniem stoją między innymi samorządy lokalne. Zadaniem ich jest m.in.: kształtowanie indywidualnych postaw przedsiębiorczych, zachęcanie do podejmowania działalności gospodarczej i tworzenie warunków ułatwiających funkcjonowanie firmy. Najważniejszym działaniem, jakiego mogą podjąć się władze samorządu lokalnego, jest umożliwienie sprawnego działania przedsiębiorstwa, a wręcz jego nieutrudnianie ${ }^{2}$.

W pracy podjęto próbę zbadania oddziaływania instytucji, zwłaszcza lokalnych samorządów terytorialnych, na przedsiębiorców i osoby planujące założyć własną działalność gospodarczą. Badanie zrealizowano w gminie znajdującej się na terenie województwa podlaskiego. Przeprowadzone analizy posłużyły weryfikacji hipotezy wskazującej na znaczny udział instytucjonalnych uwarunkowań w pobudzaniu przedsiębiorczości w społeczeństwie.

\section{Wpływ lokalnego środowiska instytucjonalnego na kształtowanie się przedsiębiorczości}

Zdefiniowanie pojęcia instytucji dostarcza wielu trudności. Wynika to z zastosowania wielu perspektyw interpretacyjnych. Wśród przedstawicieli ekonomii zajmującymi się tą tematyką można wymienić T. Veblena. Uważał on, iż instytucja to zwyczaj, który został przyjęty przez społeczeństwo i jest powszechnie akceptowany $^{3}$. Natomiast O. Williamson dowodzi, że instytucje można definiować jako społeczne ramy kontroli, w zakresie których mogą być prowadzone działania indywidualne ${ }^{4}$. G.M. Hodgson interpretuje instytucje jako trwałe reguły i normy społeczne, określające interakcje międzyludzkie. Reguły te jednocześnie

\footnotetext{
${ }^{1}$ D. Walczak, A. Żołądkiewicz, Wybrane determinanty rozwoju przedsiębiorczości $w$ Polsce, „Roczniki Naukowe Stowarzyszenia Ekonomistów Rolnictwa i Agrobiznesu”, 2015, t. XVII, z. 3, s. 398.

${ }^{2}$ K. Kuciński, Przedsiębiorczość a rozwój regionalny w Polsce, Wydawnictwo Difin, Warszawa 2010, s. 18.

${ }^{3}$ T. Veblen, Absentee Ownership and Business Enterprise in Recent Times: The Case of America, George Allen \& Unwin, London 1924, p. 28.

${ }^{4}$ Organization Theory: From Chester Barnard to the Present and Beyond, O. Williamson (ed.), Oxford University Press, Oxford 1995, p. 209.
} 
oddziałują na kształtowanie się zachowań jednostek, jak również mogą uniemożliwiać bądź nawet nie pozwalać na pewne zachowania ${ }^{5}$. D.C. North instytucje porównywał z regułami gry obowiązującymi w społeczeństwie, które są ograniczeniami ustalonymi przez ludzi, wpływającymi na kształtowanie się wzajemnych odziaływań międzyludzkich ${ }^{6}$. W niektórych ujęciach można spotkać utożsamienie instytucji $\mathrm{z}$ organizacjami ${ }^{7}$. Takie stanowisko jest prezentowane między innymi przez E. Stiglitza ${ }^{8}$. Interpretacja ta często jest spotykana oraz używana w języku potocznym. Podmioty tworzące regulacje i same regulacje są traktowane jednakowo. Zbieżności pomiędzy obiema kategoriami są związane z kreacją interakcji międzyludzkich. Nie jest możliwe całkowite oddzielenie działań organizacji i instytucji, czyli reguł, według których działają ludzie, grupy i całe organizacje ${ }^{9}$. Powyższa definicja została przyjęta na potrzeby artykułu do prowadzenia dalszych rozważań i badań.

Społeczeństwo składa się z dominujących systemów wzajemnych powiązań, są to właśnie instytucje formalne i nieformalne ${ }^{10}$. Wiedza zgromadzona przez pokolenia jest przekazywana kolejnym po to, aby urzeczywistniać ogólnie przyjęte: normy, zasady i reguły działania ${ }^{11}$. Właśnie taki kształt przyjmują instytucje, wywierając istotny wpływ na postawy i działania człowieka. Powszechność występowania instytucji skutkuje powstawaniem interakcji oraz zależności pomiędzy wszystkimi jednostkami i podmiotami gospodarczymi, oddziałując tym samym na wszelkie relacje tworzone $\mathrm{w}$ procesie: produkcji, wymiany i podziału wartości ${ }^{12}$. Zatem indywidualne cele i działania podmiotów gospodarczych mogą być częściowo wyjaśnione przez czynniki instytucjonalne ${ }^{13}$.

Literatura przedmiotu podkreśla znaczenie historycznego ukształtowania instytucji, co sprawia, że rozpatrywanie jej jedynie w odniesieniu do sformalizowanych jednostek nie ukazuje całościowego wpływu wszystkich rodzajów instytucji. Można odnaleźć i wskazać duży udział nieformalnych instytucji, wykształconych w długotrwałym procesie historycznym. Przeszłe zdarzenia oddziałują na obecnie odnoszone sukcesy bądź porażki i to tam należy poszukiwać ich przyczyn. Podejmowanie decyzji zawsze jest poprzedzone analizą przeszłych:

${ }^{5}$ G.M. Hodgson, What are Institutions?, “Journal of Economics Issues”, 2006, vol. 40(1), p. 1-25.

${ }^{6}$ D.C. North, Institutions, Institutional Change and Economic Performance, Cambridge University Press, New York 1990, p. 4.

7 M. Gancarczyk, Instytucje a organizacja $w$ nowej ekonomii instytucjonalnej, „Gospodarka Narodowa", 2002, nr 5-6, s. 82-83.

${ }^{8}$ E. Stiglitz, Challenges in the Analysis of the Role of Institutions in Economic Development, Villa Bording Workshop Series, The Institutional Foundations of a Market Economy, 2000, p. 15-28.

${ }^{9}$ E. Gruszewska, Instytucje a proces tworzenia kapitału $w$ Polsce, Wydawnictwo Uniwersytetu w Białymstoku, Białystok 2013, s. 100.

${ }^{10}$ V. Nee, R. Swedberg, Economic Sociology and New Institution Economics, "Handbook of New Institutional Economic", C. Menard, M.M. Shirley (eds.), Springer, Dordrecht 2005, p. 797.

${ }^{11}$ A. Jakubowska, A. Grabowska-Powaga, Instytucje a aktywność gospodarcza podmiotów - wybrane aspekty, „Zeszyty Naukowe Politechniki Śląskiej”, 2016, nr kol. 1964, z. 97, s. 405.

${ }^{12}$ E. Gruszewska, Instytucje a proces tworzenia ..., op. cit., s. 100.

${ }^{13}$ G.M. Hodgson, Institutional Economics into the Twenty-First Century, "Studie Note di Economia”, 2009, vol. 14, no. 1, p. 9. 
zdarzeń, doświadczeń oraz wiedzy posiadanej przez jednostkę. Wydarzenia historyczne mają wpływ na kierunki rozwoju, dlatego też każdy kraj jest inny i podejmuje odmienne działania, idąc własną drogą. Przyczyny współcześnie występujących barier gospodarczych również można odnaleźć $\mathrm{w}$ trakcie rozważania przeszłych zdarzen ${ }^{14}$. Dysponowanie odpowiednim zakresem wiedzy z zakresu historii pozwala na zrozumienie przyczyny niepowodzenia. Na podstawie takiej analizy przy podejmowaniu kolejnych decyzji dysponuje się przewagą, dzięki której można przewidzieć skutki oraz spojrzeć na dany problem z szerszej perspektywy, co zwiększa prawdopodobieństwo podjęcia dobrego wyboru ${ }^{15}$. Ponadto, układy instytucjonalne są zróżnicowane wewnętrznie i podlegają ciągłym przemianom, a takie uwarunkowanie również może tłumaczyć zróżnicowanie dynamiki poszczególnych gospodarek ${ }^{16}$.

Instytucje bazują na powszechnie przyjętych normach i zasadach, stąd podmioty podejmują decyzję, odnosząc się do tych zasad. Warto podkreślić, iż taka możliwość występuje jedynie w dobrze unormowanych i zorganizowanych instytucjach $^{17}$. Nie każda instytucja i jej działanie ma pozytywny wpływ. Mogą być instytucje złe, które reagują zniechęcająco na każdą formę działalności, odciągają od wysiłków czy podejmowania ryzyka, powodują one hamowanie przedsiębiorczości. Instytucje pozytywne sprzyjają rozwojowi, umożliwiają rozwój techniczny i społeczny, zapewniają stabilność, a jednocześnie wyróżniają się elastycznością w dostosowaniu się do zmiennych warunków ${ }^{18}$. Dobrze działające wspierają wszelką działalność gospodarczą, ponieważ jednym z głównych celów oddziaływania instytucji jest maksymalizowanie dobrobytu jednostek i społeczeństwa $^{19}$. Instytucje powinny generować bodźce do rywalizacji podmiotów między sobą, równocześnie zapobiegając postępowaniu wbrew ustalonym regułom. W przypadku działania jednostek wbrew przyjętym zasadom, instytucje powinny oddzielać jednostki działające zgodnie z regułami od tych nieprzestrzegających $^{20}$.

Instytucje wpływają na jednostkę poprzez formowanie sposobu myślenia, zachowania i postaw. Mają swój udział w kształtowaniu aspiracji oraz umiejętnie realizują określone cele. Instytucje ulegają utrwaleniu przez to, że ludzie postępują według tych zasad, jednak w sposób mniej lub bardziej świadomy mogą je stopniowo przekształcać. Każdy system instytucjonalny w różnym stopniu oddziałuje na przedsiębiorczość, generując bodźce o zmiennym natężeniu ${ }^{21}$.

\footnotetext{
${ }^{14}$ B. Glinka, Kulturowe uwarunkowania przedsiębiorczości $w$ Polsce, Polskie Wydawnictwo Ekonomiczne, Warszawa 2008, s. 62-63.

${ }^{15}$ D.C. North, Institutions, Institutional Change ..., op. cit., p. 38.

${ }^{16}$ E. Gruszewska, Instytucje a proces tworzenia ..., op. cit., s. 114.

${ }^{17}$ A. Jakubowska, A. Grabowska-Powaga, Instytucje a aktywność gospodarcza ..., op. cit., s. 406.

${ }^{18}$ G. Kołodko, Wędrujący świat, Wydawnictwo Prószyński i s-ka, Warszawa 2008, s. 294.

${ }^{19}$ E. Gruszewska, Instytucje a proces tworzenia ..., op. cit., s. 151.

${ }^{20}$ Ibidem, s. 151.

${ }^{21}$ Ibidem, s. 271.
} 
Instytucje rzutują na stosunek ludzi do otoczenia i tym samym na intensywność oraz kierunek działań przedsiębiorców. Instytucje społeczne kształtują zakres jakiejkolwiek działalności człowieka, oddziałują na postrzeganie otaczającego świata, a także interpretację zachodzących zjawisk i zdarzeñ ${ }^{22}$. Istotność roli, jaką odgrywają instytucje w stosunku do generowania przedsiębiorczości, jest duża. Mają one wpływ na jednostki i grupy przez cały czas, ukierunkowując ich działanie poprzez stosowanie bodźców o odpowiedniej intensywności i w poszczególnych obszarach. Ważny wpływ instytucji na przedsiębiorców wynika z faktu, iż to oni zmieniają gospodarczy świat. Obecnie są obserwowane silne i wielopoziomowe zależności między instytucjami a przedsiębiorczością. Przedsiębiorczość można również uznać za instytucję, ponieważ kształtuje działania ludzkie ${ }^{23}$.

Wpływ instytucji na działalność podmiotów gospodarczych może być bezpośredni i pośredni ${ }^{24}$. Bezpośrednie oddziaływanie polega na tworzeniu bodźców, które wprost wywołują wzrost albo spadek dynamiki produkcji bądź obrotów. Za pomocą takiej stymulacji instytucje mogą determinować: dobór czy strukturę czynników produkcji, technologię, innowacyjność, organizację i wydajność pracy. Pośrednie oddziaływanie polega na stymulowaniu otoczenia np. za pomocą zarządzania: rozmaitymi konfliktami etnicznymi, polityką gospodarczą, stanem i zasobem kapitału społecznego. Sprawne funkcjonowanie instytucji wpływa na aktywność podmiotów oraz na wzrost ich konkurencyjności, co w dłuższym okresie przekłada się na wzrost i rozwój gospodarczy kraju.

Instytucje mają udział w kształtowaniu otoczenia, w którym mogą ujawnić się cechy i postawy przedsiębiorcze. Dzięki kumulacji wiedzy rozpowszechnionej w społeczeństwie, a następnie jej udostępnieniu w postaci informacji przyczyniają się do zwiększenia aktywności podmiotów. Prowadzenie działalności gospodarczej jest znacznie łatwiejsze, gdy dobrze funkcjonują instytucje ${ }^{25}$. Jednym z przykładów wpływu instytucji na przedsiębiorczość jest transformacja systemowa Polski. Pojawienie się wolnego rynku, na przełomie lat osiemdziesiątych i dziewięćdziesiątych XX wieku, wywołało powstanie ogromnej ilości nowych podmiotów gospodarczych ${ }^{26}$.

Ostatnie badania prowadzone przez C.R. Williamson dowodzą, iż kraje, w których są silne instytucje formalne i nieformalne oraz słabe instytucje formalne, ale mocne nieformalne, osiągają wyższy poziom PKB per capita w porównaniu z krajami, gdzie są słabe instytucje formalne i nieformalne oraz silne formalne, lecz słabe instytucje nieformalne ${ }^{27}$. Zróżnicowanie ma miejsce również

\footnotetext{
${ }^{22}$ Ibidem, s. 113.

${ }^{23}$ Ibidem, s. 270.

${ }^{24}$ A. Jakubowska, A. Grabowska-Powaga, Instytucje a aktywność gospodarcza ..., op. cit., s. 406.

${ }^{25}$ D.C. North, Institutions, Institutional Change ..., op. cit., p. 28.

${ }^{26}$ T. Piecuch, Przedsiębiorczość - podstawy teoretyczne, Wydawnictwo C.H. Beck, Warszawa 2013, s. 98-99.

${ }^{27}$ C.R. Williamson, Informal institutions rule: institutional arrangements and economic performances, "Public Choice", 2009, no. 3-4, t. 139, p. 377.
} 
pomiędzy krajami, gdzie są słabe instytucje formalne, a silne nieformalne. Tam poziom PKB per capita jest wyższy, niż w krajach o silnych instytucjach formalnych i nieformalnych ${ }^{28}$. Cechą łączącą obie badane grupy jest obecność silnych i dobrze ukształtowanych instytucji nieformalnych. Badania te obrazują i potwierdzają, że instytucjonalne uwarunkowania, występujące w danym kraju, istotnie rzutują na działania podejmowane przez mieszkańców. Wzajemne powiązanie instytucji i wysokości PKB pokazuje wpływ instytucji na przedsiębiorczość. Instytucje dobrze zorganizowane wspierają i popularyzują przedsiębiorczość. Ciekawym aspektem jest większy udział instytucji nieformalnych w kształtowaniu postaw przedsiębiorczych, a to można powiązać z dodatkowym wpływem kultury oraz postaw utrwalonych w społeczeństwie. Ponadto, badania te świadczą o tym, iż kształtowanie się przedsiębiorczości to długi proces, złożony i wielowymiarowy, na który oddziałuje wiele czynników.

\section{Działalność instytucji lokalnych na rzecz przedsiębiorczości}

W systemie wspierania przedsiębiorczości i przedsiębiorstw w Polsce można wyróżnić podmioty działające na trzech poziomach, tj.: krajowym, wojewódzkim i lokalnym. Do poziomu krajowego można zaliczyć m.in.: Ministerstwo Gospodarki, Polską Agencję Rozwoju Przedsiębiorczości, a do poziomu wojewódzkiego m.in.: Urzędy Marszałkowskie, Regionalne Instytucje Finansujące oraz szczebel lokalnych usługodawców. Wśród lokalnych usługodawców można wymienić organizacje zarejestrowane w Krajowym Systemie Usług dla MŚP, w tym m.in.: Punkty Konsultacyjne, ośrodki Enterprise Europe Network, Fundusze Poręczeń Kredytowych, Fundusze Pożyczkowe, Krajową Sieć Innowacji. Podmioty te zajmują się formułowaniem strategii, programów i wdrażaniem działań na rzecz wsparcia przedsiębiorczości ${ }^{29}$.

Przewaga jednostek samorządu terytorialnego nad każdą inną instytucją wspierającą przedsiębiorczość umożliwia wykorzystanie wielu narzędzi, które mają na celu kreację najkorzystniejszych warunków zarówno w stosunku do podmiotów gospodarczych istniejących, jak i nowo powstających ${ }^{30}$. Celem samorządów jest promowanie postaw przedsiębiorczych, jak również udzielanie rzetelnych informacji przedsiębiorcom i osobom planującym rozpoczęcie działalności gospodarczej na temat: programów wsparcia, możliwości pomocy w zakresie szkoleń, doradztwa oraz finansowym. Taka pomoc jest niezwykle przydatna dla obecnych i przyszłych przedsiębiorców ${ }^{31}$. Największymi możliwościami wspierania przedsiębiorczości dysponują gminy. Jest to związane

\footnotetext{
${ }^{28}$ A. Jakubowska, A. Grabowska-Powaga, Instytucje a aktywność gospodarcza ..., op. cit., s. 408.

${ }^{29}$ R. Majkut, Przedsiębiorczość $w$ świetle uwarunkowań interdyscyplinarnych, CeDeWu, Warszawa 2014, s. 89.

${ }^{30}$ D. Walczak, A. Żołądkiewicz, Wybrane determinanty rozwoju ..., op. cit., s. 398.

${ }^{31}$ R. Majkut, Przedsiębiorczość w świetle uwarunkowań ..., op. cit., s. 90.
} 
z zapisem znajdującym się w Konstytucji Rzeczypospolitej Polskiej ${ }^{32}$, w której gminom przypisano największy zakres zadan ${ }^{33}$. Gminne samorządy mogą wykorzystać instrumenty finansowe, takie jak: zwolnienia i ulgi podatkowe, obniżanie stawek podatkowych, wprowadzanie korzystnych opłat za grunty i wynajem nieruchomości. Władze lokalne mogą oddziaływać na przedsiębiorczość dzięki ustalaniu wysokości wydatków samorządu na inwestycje oraz budowie i modernizacji infrastruktury technicznej. Samorząd lokalny odpowiada za sprawność funkcjonowania administracji publicznej. Narzucone standardy obsługi przedsiębiorców i podejmowanie uchwał o korzystnych bądź niekorzystnych warunkach w odniesieniu do przedsiębiorców wpływają pośrednio bądź bezpośrednio na możliwości funkcjonowania i rozwój firm ${ }^{34}$. Aby skutecznie stymulować przedsiębiorczość na poziomie lokalnym, należy uruchamiać procesy trwałego, zrównoważonego rozwoju lokalnego i regionalnego, a także przywiązywać większą wagę do kultury organizacyjnej urzędów gmin ${ }^{35}$.

Pobudzanie przedsiębiorczości na poziomie gminnym i jej wykorzystanie w procesach rozwoju lokalnego i regionalnego zależy w dużej mierze od urzędów gmin, które oddziałują na rzecz stymulowania i zarządzania rozwojem lokalnym. Jednak rozwój przedsiębiorczości zależy również od tego, jacy przedsiębiorcy są w danej gminie i jaka jest lokalna społecznośćc ${ }^{36}$. Działalność gospodarczą warunkuje niezliczona liczba czynników związanych z podmiotem decydującym się na założenie działalności. Do powstania przedsiębiorstwa są potrzebne odpowiednie warunki stworzone przez instytucje, umożliwiające prowadzenie działalności. Uwarunkowaniom takim służy głównie otoczenie lokalne, w tym działalność samorządu lokalnego. Otoczenie to można uważać za środowisko zewnętrzne, które determinuje funkcjonowanie i rozwój przedsiębiorstwa ${ }^{37}$. Przedsiębiorstwo działa dzięki otoczeniu, bez niego nie mogłoby istnieć i funkcjonować, przesądza ono o jego powstaniu i rozwoju, jednocześnie wyznaczając obszar, w którym może poruszać się dane przedsiębiorstwo. Instytucje i podmioty oddziałują na siebie wzajemnie ${ }^{38}$. Podstawą działania instytucji jest określenie ram, w których przedsiębiorstwo może funkcjonować, a zarazem promocja pewnych działań na swoim obszarze. Natomiast podmioty gospodarcze dostosowują się do określonych norm i zasad, a przez to mogą wpływać na kształt instytucji.

\footnotetext{
${ }^{32}$ Konstytucja Rzeczypospolitej Polskiej z dnia 2 kwietnia 1997 roku (Dz.U. 1997, Nr 78, poz. 48).

${ }^{33}$ D. Walczak, A. Żołądkiewicz, Wybrane determinanty rozwoju ..., op. cit., s. 398.

${ }^{34}$ A. Kamińska, Regionalne determinanty rozwoju matych $i$ średnich przedsiębiorstw, Wydawnictwo Difin, Warszawa 2011, s. 50.

${ }^{35}$ K. Kuciński, Przedsiębiorczość a rozwój regionalny ..., op. cit., s. 19.

${ }^{36}$ Ibidem, s. 19.

${ }^{37}$ A. Kamińska, Regionalne determinanty rozwoju matych $i$ średnich ..., op. cit., s. 39.

${ }^{38}$ A. Jakubowska, A. Grabowska-Powaga, Instytucje a aktywność gospodarcza ..., op. cit., s. 405.
} 


\section{Materiał i metoda badawcza}

Na potrzeby artykułu zostało przeprowadzone badanie empiryczne, które miało na celu analizę poglądów oraz opinii osób prowadzących działalność gospodarczą, dotyczących czynników instytucjonalnych wpływających na podejmowanie decyzji o prowadzeniu działalności gospodarczej. Badanie zrealizowano na przełomie lutego i marca 2016 roku w gminie wiejskiej, zlokalizowanej na terytorium województwa podlaskiego w powiecie bielskim. Obszar badanej gminy Brańsk zamieszkuje 6027 mieszkańców. Kobiety stanowią około 48\% mieszkańców, a mężczyźni około $52 \%$. Powierzchnia gminy to ponad $227 \mathrm{~km}^{2}$, co obejmuje $16,41 \%$ powierzchni powiatu. Największe obszary w gminie zajmują użytki rolne, tj.: $78 \%$ powierzchni, a $15 \%$ to użytki leśne ${ }^{39}$. Znaczna część mieszkańców gminy Brańsk zajmuje się rolnictwem, gdyż ponad 98\%. Oprócz działalności rolniczej, na terenie gminy znajdują się 148 podmioty gospodarcze ${ }^{40}$. Osoby prowadzące własny biznes stanowią zaledwie $2 \%$ ogółu mieszkańców gminy ${ }^{41}$.

Badanie przeprowadzono przy użyciu ankiety jednokrotnego wyboru. W próbie badawczej znaleźli się celowo wytypowani przedsiębiorcy prowadzący działalność gospodarczą na obszarze gminy Brańsk. W badaniu uczestniczyło 60 ankietowanych, czyli ponad $40 \%$ wszystkich przedsiębiorców.

Ankietowani przedsiębiorcy deklarowali wykształcenie średnie $-44 \%$, wyższe $-33 \%$, zawodowe $-20 \%$ oraz podstawowe $-3 \%$. Największa część respondentów znalazła się w przedziale wiekowym $45-55$ lat $-32 \%$, natomiast w grupie 25-34 lata - 25\%, 56-64 lata - 18\%, 34-44 lata - 17\%. Najmłodsza grupa wiekowa (18-24 lata) stanowiła zaledwie $8 \%$ badanych. W wyniku analizy liczby zatrudnianych pracowników stwierdzono, że 51\% to firmy działające jako jednoosobowa działalność gospodarcza, 30\% to firmy zatrudniające do 10 pracowników, natomiast firmy średnie, zatrudniające powyżej 10 pracowników, stanowiły $19 \%$. Ankietowani przedsiębiorcy prowadzili głównie działalność w zakresie: handlu $40 \%$, transportu $-17 \%$, usług - $15 \%$, handlu i naprawy pojazdów samochodowych - 8\%, usług rolniczych - 5\%, usług budowlano-wykończeniowych - 5\%, usług tartacznych i związanych z leśnictwem - 3\%.

\section{Wyniki przeprowadzonych badań}

Respondenci wyrazili opinię na temat wpływu instytucji otoczenia biznesu na prowadzoną przez nich działalność gospodarczą w gminie Brańsk. Większość ankietowanych przedsiębiorców stwierdziła niską aktywność i nieznaczny wpływ instytucji otoczenia biznesu na prowadzoną działalność, w tym gronie znalazło

\footnotetext{
${ }^{39}$ Bank Danych Lokalnych, GUS, https://bdl.stat.gov.pl/BDL/start [data dostępu: 25.02.2016].

${ }^{40}$ Centralna Ewidencja i Informacja o Działalności Gospodarczej,

https://prod.ceidg.gov.pl/ceidg/ceidg.public.ui/search [data dostępu: 25.02.2016].

${ }^{41}$ Są to badania własne.
} 
się 32\% ankietowanych, a brak oddziaływania tego typu instytucji na funkcjonowanie przedsiębiorstw wytypowało $28 \%$ respondentów. Wśród pozytywnych ocen na umiarkowaną działalność wskazało $18 \%$ ankietowanych, ocenę dobrą przyznało $7 \%$ ankietowanych, a bardzo dobrą $2 \%$ ankietowanych. Wśród udzielonych odpowiedzi była grupa przedsiębiorców, która zauważyła negatywny wpływ instytucji otoczenia biznesu na prowadzoną działalność, taką odpowiedź wybrało $13 \%$ ankietowanych. Ankietowani w zdecydowanej większości ocenili działania prowadzone przez otoczenie biznesu jako mało istotne oraz niewpływające w sposób satysfakcjonujący na prowadzoną przez nich działalność gospodarczą. Jednak nie oznacza to, iż respondenci nie są świadomi możliwości wspierania przedsiębiorczości przez badane instytucje, lecz działania prowadzone w obecnym kształcie ocenili jako niewystarczające, a nawet hamujące w stosunku do niektórych firm, szczególnie z sektora MŚP.

Wykres 1.

Wpływ instytucji otoczenia biznesu na prowadzenie działalności gospodarczej w opinii ankietowanych przedsiębiorców

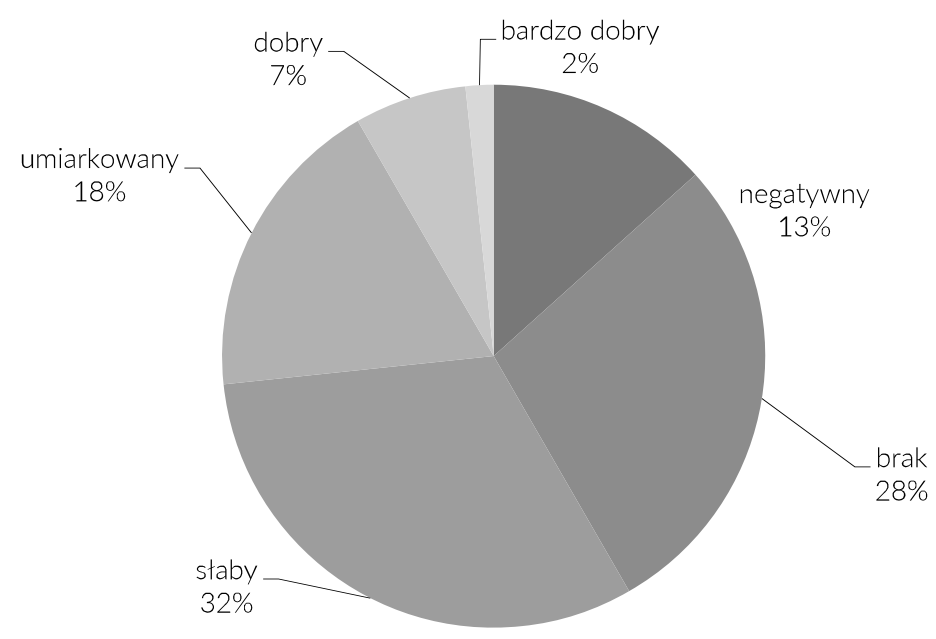

Źródło: wyniki badań własnych.

Przedsiębiorcy, biorący udział w badaniu, ocenili również zainteresowanie oraz wsparcie samorządu lokalnego gminy Brańsk kierowane do miejscowych przedsiębiorców. W opinii 52\% ankietowanych, działalność samorządu skierowana do przedsiębiorców jest niewystarczająca i została oceniona jako słaba. Natomiast $28 \%$ przedsiębiorców, biorących udział w badaniu, nie dostrzegało żadnych działań skierowanych do osób prowadzących przedsiębiorstwa bądź chcących w przyszłości otworzyć własną firmę. Ocenę dostateczną dla władz samorządu lokalnego wystawiło zaledwie $13 \%$ ankietowanych, a także mała grupa 
7\% przedsiębiorców uznała prowadzone działania za dobre. W ocenie przedsiębiorców, prowadzących działalność na terenie badanej gminy, działania podejmowane przez władze gminne są niezadowalające albo nie występują. Odpowiedzi respondentów wyrażały mały stopień skuteczności bądź małą liczbę działań podejmowanych przez samorząd lokalny na rzecz przedsiębiorców. Gmina zdaje się nie zauważać tej grupy i nie stara się kreować działań przyjaznych dla osób prowadzących działalność gospodarczą.

Wykres 2.

Ocena działań samorządu lokalnego skierowanych do przedsiębiorców w opinii ankietowanych

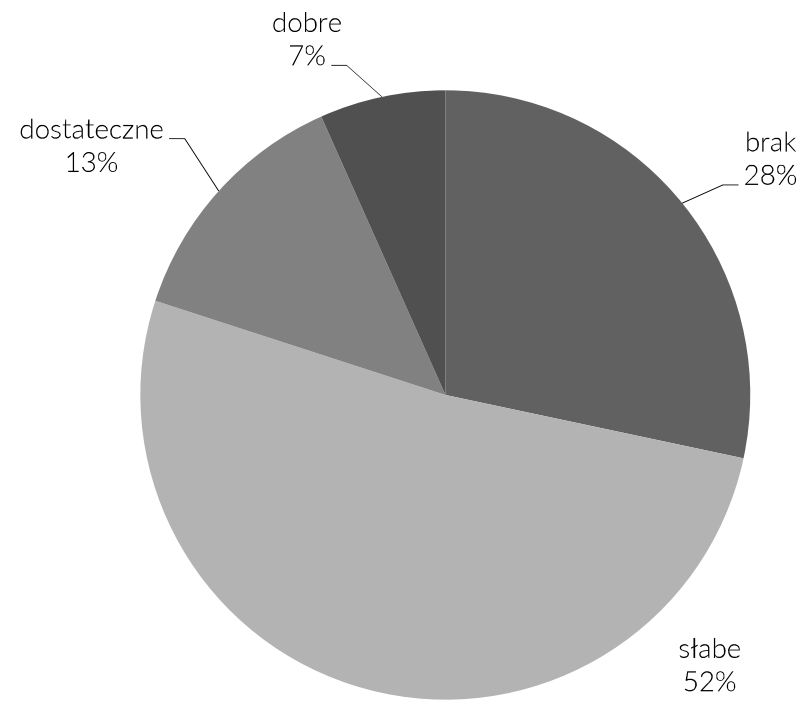

Źródło: wyniki badań własnych.

Badani przedsiębiorcy zostali zapytani o to, jakie działania mogłyby podjąć władze gminne, aby wesprzeć działalność gospodarczą prowadzoną przez ankietowanych. Głównym działaniem samorządów lokalnych, według respondentów, mogłoby być obniżenie wszelkich opłat oraz zastosowanie zwolnień podatkowych. Taką opinię wyraziło $43 \%$ ankietowanych przedsiębiorców. Kolejnym elementem istotnym dla przedsiębiorców, a leżącym w gestii władz lokalnych, w uznaniu $32 \%$ ankietowanych, powinny być realizacje inwestycji, które miałyby na celu rozwój gminy i podnoszenie jej atrakcyjności na tle innych. Ankietowani przede wszystkim zwrócili uwagę na potrzebę poprawy stanu infrastruktury. Wśród $16 \%$ badanych przedsiębiorców pojawiły się spostrzeżenia dotyczące braku odpowiedniej informacji o szkoleniach i kursach w zakresie pozyskiwania funduszy ze środków Unii Europejskiej. Ponadto, 7\% ankietowanych stwierdziło 
luki w informacji oraz brak organizacji różnych szkoleń, które służyłyby podnoszeniu kwalifikacji mieszkańców i przedsiębiorców. Zgodnie z opinią przedsiębiorców, gmina dysponuje wieloma instrumentami wsparcia, które mogłyby zostać wdrożone i zastosowane. Największym oczekiwaniem w stosunku do władz gminnych jest wykorzystanie ulg i zwolnień podatkowych oraz rozbudowa infrastruktury.

\section{Wykres 3.}

Opinie ankietowanych przedsiębiorców na temat możliwości wsparcia działalności gospodarczej przez władze gminne

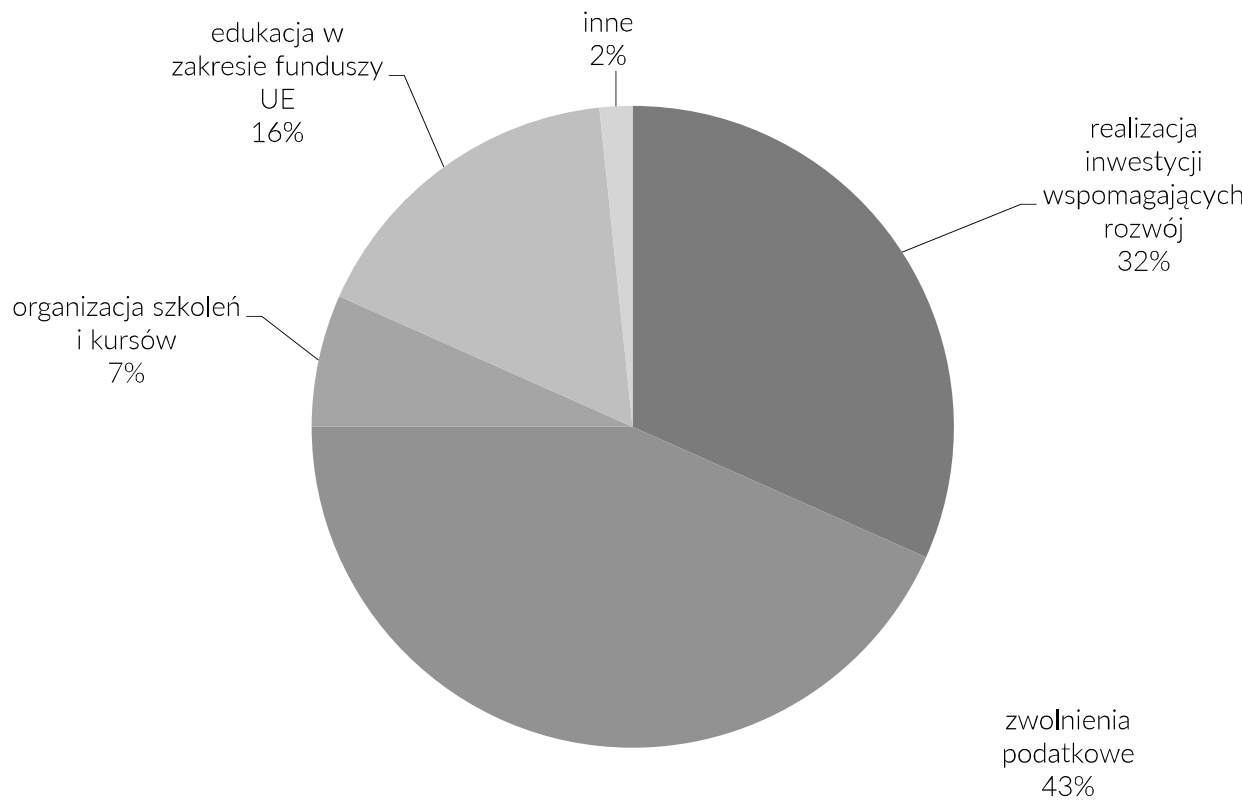

Źródło: wyniki badań własnych.

Wśród barier w prowadzeniu działalności gospodarczej ankietowani przedsiębiorcy bardzo często podawali duże obciążenie ze strony państwa i taką opinię wyraziło $63 \%$ respondentów. Za kolejną, istotną przeszkodę, utrudniającą prowadzenie własnej działalności, badani uznali brak czasu dla rodziny $-22 \%$ przedsiębiorców. Natomiast $13 \%$ ankietowanych wskazało brak wsparcia przedsiębiorców lokalnych przez władze samorządowe. Najmniejsza część ankietowanych przedsiębiorców, zaledwie $2 \%$, podała występujące, negatywne reakcje ze strony społeczeństwa. Przedsiębiorcy napotykają wiele przeszkód związanych z prowadzeniem firm, jednak największym ograniczeniem, według ankietowanych, jest obciążenie działalności gospodarczej znaczną liczbą podatków i opłat. Dodatkowo skomplikowane prawo, niejasne procedury, duża liczba formalności i regulacji zniechęcają do tworzenia nowych firm oraz hamują rozwój już istniejących. 
Wykres 4.

Najważniejsze bariery w prowadzeniu działalności gospodarczej w opinii ankietowanych przedsiębiorców

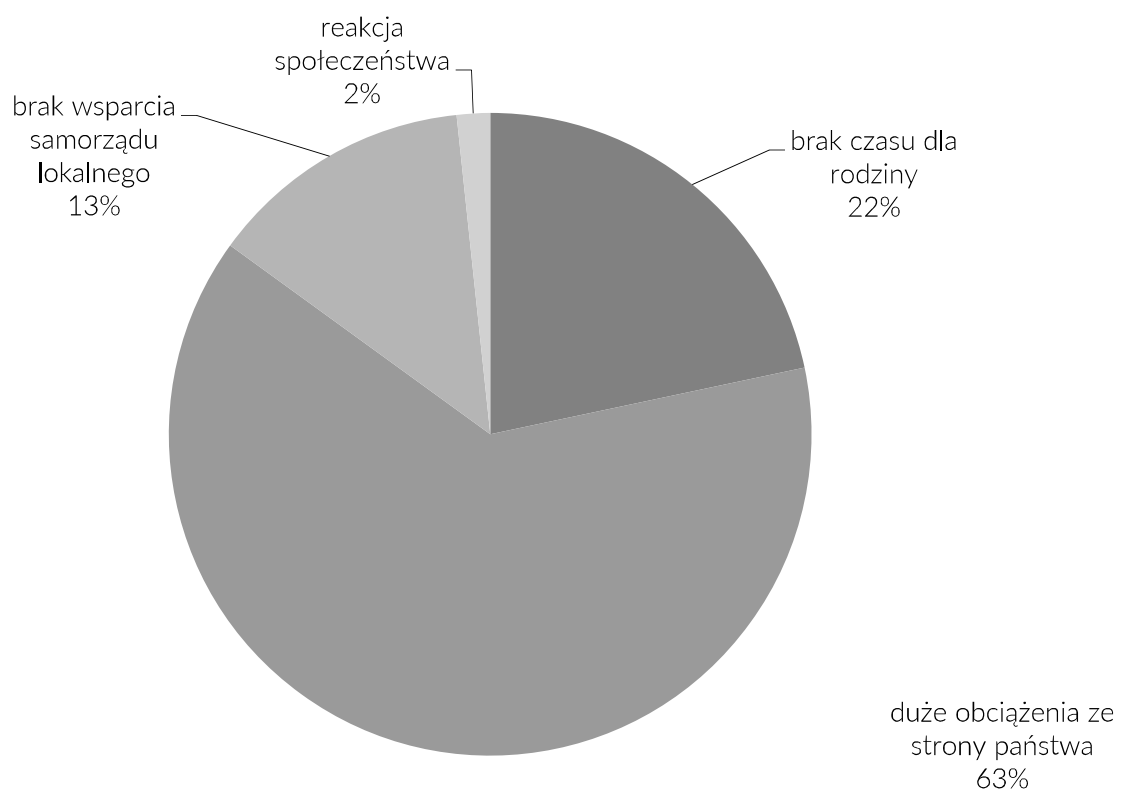

Źródło: wyniki badań własnych.

Z przeprowadzonego badania wynika, że osoby prowadzące działalność gospodarczą na obszarze gminy Brańsk niezbyt chętnie sięgały po fundusze pochodzące ze środków Unii Europejskiej. Jedynie 20\% ankietowanych przedsiębiorców korzystało z takiego wsparcia finansowego. Brak prób pozyskiwania środków zadeklarowało $80 \%$ ankietowanych. Przedsiębiorcy nie byli zainteresowani ani nie podejmowali żadnych wysiłków, które miałyby na celu zdobycie informacji dotyczących pozyskania środków z dofinansowania Unii Europejskiej. Przedsiębiorcy, którzy prowadzili jednoosobową działalność, najrzadziej deklarowali korzystanie z dotacji, a ponad $94 \%$ ankietowanych wskazało, że nie korzystało ze środków oferowanych przez Unię Europejską. Odsetek ten zmniejszał się wraz ze wzrostem wielkości firmy. W przedsiębiorstwach, zatrudniających powyżej 10 pracowników, $72 \%$ ankietowanych nie korzystało z dotacji pochodzących ze źródeł Unii Europejskiej. W przypadku przedsiębiorców, zatrudniających powyżej 10 pracowników, aż $45 \%$ ankietowanych korzystało z takich funduszy. Może to być związane $z$ lepszym dostępem do informacji na temat dodatkowych źródeł finansowania działalności przez większe podmioty i tym samym większym zapotrzebowaniem na kapitał. 
Wykres 5.

Stanowisko ankietowanych przedsiębiorców dotyczące korzystania ze środków finansowych Unii Europejskiej w podziale na wielkość prowadzonej działalności

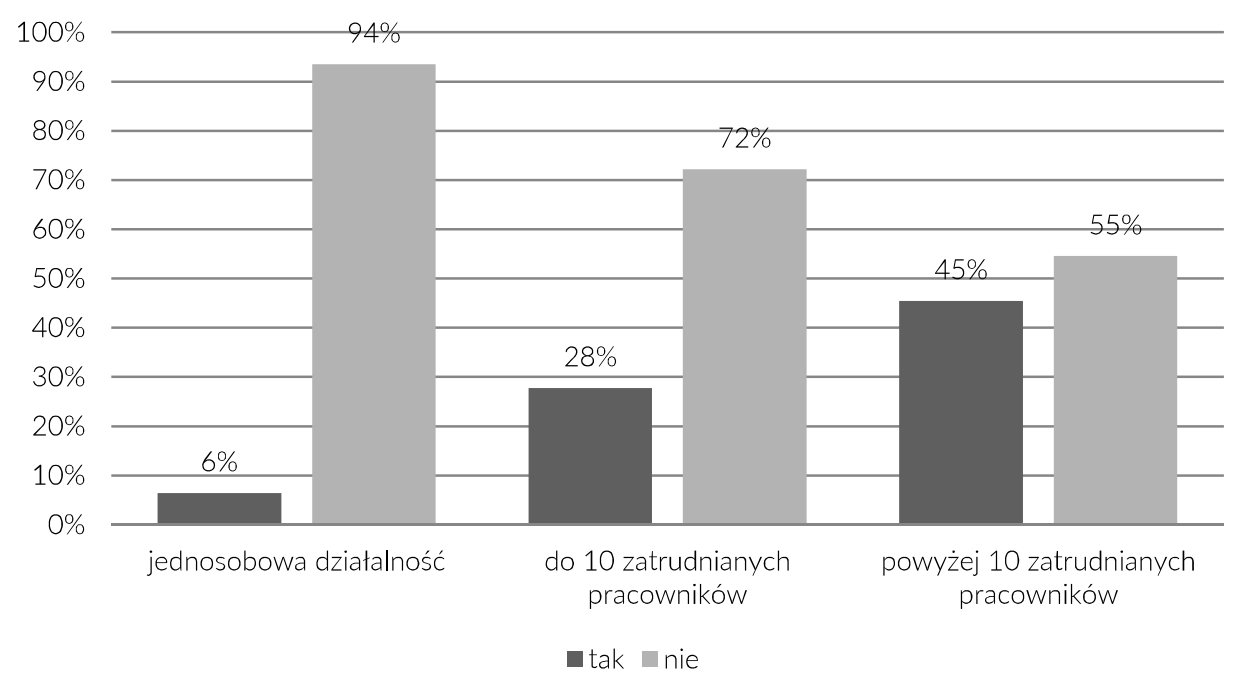

Źródło: wyniki badań własnych.

Zdaniem ankietowanych, najczęstszym powodem, dla którego przedsiębiorcy nie ubiegali się o fundusze pochodzące z Unii Europejskiej, były skomplikowane procedury, a $46 \%$ respondentów, deklarujących niekorzystanie z funduszy Unii Europejskiej, podało tę odpowiedź. Wśród innych przyczyn znalazły się: niechęć do korzystania $\mathrm{z}$ tego typu wsparcia - 19\%, trudny dostęp do informacji na temat pozyskiwania funduszy z Unii Europejskiej - 13\%, zbyt wysoki wkład własny $-12 \%$, a także duża liczba chętnych do skorzystania $\mathrm{z}$ tego typu wsparcia $-10 \%$. Ankietowani przedsiębiorcy wielokrotnie wskazywali na niedostateczny poziom informacji na temat funduszy Unii Europejskiej, jak również nieznajomość formalnych procedur związanych z dostępem do środków.

Wśród problemów poruszanych w ankiecie skierowanej do przedsiębiorców została zawarta kwestia dalszych planów dotyczących przyszłości prowadzonej działalności gospodarczej. W grupie ankietowanych przedsiębiorców 87\% zadeklarowało kontynuację prowadzenia działalności gospodarczej oraz chęć dalszego rozwoju. Jedynie $13 \%$ respondentów zamierza zamykać swoją działalność i wycofywać się z rynku. Znaczna część badanych przedsiębiorców, pomimo niedogodności, barier i utrudnień, ma zamiar kontynuować i rozwijać swoją działalność. 


\section{Podsumowanie}

Przeprowadzone rozważania, które miały na celu ukazanie wpływu instytucji lokalnych na kształtowanie się postaw przedsiębiorczych, nie pozwalają na jednoznaczną weryfikację hipotezy postawionej na początku pracy, iż instytucje mają zdecydowany udział $\mathrm{w}$ pobudzaniu i kształtowaniu przedsiębiorczości w społeczeństwie. Z badań tych wynika, że instytucje, działające na terenie badanej gminy, nie mają aż tak istotnego wpływu, jak w postawionej hipotezie. Ankietowani przedsiębiorcy dostrzegali wpływ instytucji na prowadzoną działalność gospodarczą, lecz w dużym stopniu były to działania negatywne i daremne, a więc nie wpłynęły zasadniczo na pobudzanie przedsiębiorczości u ankietowanych. Jednakże badani przedsiębiorcy mogli nie być całkowicie świadomi badanego zjawiska i oddziaływania instytucji przedstawionych $\mathrm{w}$ analizie literatury przedmiotu. W niektórych przypadkach część przedsiębiorców wykazała nieznajomość kompetencji, jakimi dysponuje gmina. Badani przyznali, że działalność instytucji lokalnych, w tym gmin, oddziałuje na ich przedsiębiorstwa. Stwierdzili również, że takie działania mogą być pozytywne.

Przedsiębiorcy wskazali na słabość instytucji lokalnych w badanej gminie. Ogólnie instytucje zostały nieco lepiej ocenione, niż działalność władz samorządu gminy. Za największe utrudnienie w prowadzeniu działalności gospodarczej ankietowani uznali duże obciążenie ze strony państwa oraz niedostateczne wsparcie samorządu lokalnego. Przedsiębiorcy w zdecydowanej większości negatywnie ocenili działalność gminy, stwierdzili niską aktywność, niedostateczne zainteresowanie oraz brak wsparcia i niepodejmowanie żadnych działań skierowanych do przedsiębiorców. Przedsiębiorcy oczekują od samorządów lokalnych działań, które miałyby na celu ułatwienie prowadzenia firmy. Mogłyby nimi być: obniżenie wszelkich opłat, zastosowanie zwolnień podatkowych oraz realizacja inwestycji, które przyczyniłyby się do rozwoju gminy i podniosłyby jej atrakcyjność. Pomimo występowania instrumentów, które pobudziłyby przedsiębiorczość i wpłynęłyby pozytywnie na osoby prowadzące działalność gospodarczą, władze gminy nie są zbytnio zainteresowane rozwojem gminy i przedsiębiorczości.

Wszechobecne, niekorzystne warunki nie zniechęcają jednak przedsiębiorców do prowadzenia swojej działalności i realizacji zamierzonych celów. Znaczna część respondentów zamierza kontynuować swoją działalność. Poddani różnorakim oddziaływaniom ze strony instytucji, ale zarazem kultury i społeczeństwa potrafią podjąć inicjatywę i rozpocząć działanie. Dlatego istotne jest, aby jak najwięcej osób odkryło swoje predyspozycje i miało szansę wprowadzić własne pomysły i innowacje w życie. Otoczenie, przy pomocy instytucji, oddziela przedsiębiorców teoretycznych od tych, którzy podejmują działanie. Odseparowuje jednostki zdolne w danych warunkach podjąć ryzyko prowadzenia własnej firmy, lecz jednocześnie hamuje decyzje wielu osób o cechach przedsiębiorczych w podjęciu takiej działalności. Jeżeli instytucje na poziomie lokalnym byłyby 
bardziej przyjazne i skierowały jakiekolwiek działania $\mathrm{ku}$ promowaniu przedsiębiorczości, mogłoby to spowodować pojawienie się nowych przedsiębiorców, którzy stanowiliby najlepszy kapitał z możliwych. Ich działalność wpłynęłaby dodatnio nie tylko na nich i ich firmy, a równocześnie na całe społeczeństwo, pobudzając ducha przedsiębiorczości i uruchamiając lawinę korzystnych następstw. Na tym zyskałoby całe społeczeństwo i to nie jedynie lokalne i regionalne, a cały kraj.

\section{Literatura}

Gancarczyk M., Instytucje a organizacja w nowej ekonomii instytucjonalnej, „Gospodarka Narodowa", 2002, nr 5-6.

Glinka B., Kulturowe uwarunkowania przedsiębiorczości w Polsce, Polskie Wydawnictwo Ekonomiczne, Warszawa 2008.

Gruszewska E., Instytucje a proces tworzenia kapitatu w Polsce, Wydawnictwo Uniwersytetu w Białymstoku, Białystok 2013.

Hodgson G. M., Institutional Economics into the Twenty-First Century, "Studie Note di Economia", 2009, vol. 14, no. 1.

Hodgson G. M., What are Institutions?, "Journal of Economics Issues", 2006, no. 40(1).

Jakubowska A., Grabowska-Powaga A., Instytucje a aktywność gospodarcza podmiotów wybrane aspekty, „Zeszyty Naukowe Politechniki Śląskiej”, 2016, nr 1964, z. 97.

Kamińska A., Regionalne determinanty rozwoju matych $i$ średnich przedsiębiorstw, Wydawnictwo Difin, Warszawa 2011.

Kołodko G., Wędrujący świat, Wydawnictwo Prószyński i s-ka, Warszawa 2008.

Konstytucja Rzeczypospolitej Polskiej z dn. 2 kwietnia 1997 roku (Dz.U. 1997, Nr 78, poz. 48).

Kuciński K., Przedsiębiorczość a rozwój regionalny w Polsce, Wydawnictwo Difin, Warszawa 2010.

Majkut R., Przedsiębiorczość w świetle uwarunkowań interdyscyplinarnych, CeDeWu, Warszawa 2014.

Możyłowski P., Prawno-administracyjne bariery prowadzenia działalności gospodarczej $w$ Polsce $w$ świetle opinii przedsiębiorców oraz raportów Doing Business, „Przedsiębiorczość - Edukacja", 2013, nr 9.

Nee V., Swedberg R., Economic Sociology and New Institution Economics, „Handbook of New Institutional Economic", C. Menard, M.M. Shirley (eds.), Springer, Dordrecht 2005.

North D.C., Institutions, Institutional Change and Economic Performance, Cambridge University Press, New York 1990.

Organization Theory: From Chester Barnard to the Present and Beyond, O. Williamson (ed.), Oxford University Press, Oxford 1995.

Piecuch T., Przedsiębiorczość - podstawy teoretyczne, Wydawnictwo C.H. Beck, Warszawa 2013.

Stiglitz E., Challenges in the Analysis of the Role of Institutions in Economic Development, Villa Bording Workshop Series, The Institutional Foundations of a Market Economy, 2000. 
Veblen T., Absentee Ownership and Business Enterprise in Recent Times: The Case of America, George Allen \& Unwin, London 1924.

Walczak D., Żołądkiewicz A., Wybrane determinanty rozwoju przedsiębiorczości $w$ Polsce, „Roczniki Naukowe Stowarzyszenia Ekonomistów Rolnictwa i Agrobiznesu”, 2015, t. XVII, z. 3.

Williamson C.R., Informal institutions rule: institutional arrangements and economic performances, "Public Choice”, 2009, no. 3-4, t. 139.

\section{Materiały elektroniczne}

Bank Danych Lokalnych, GUS, https://bdl.stat.gov.pl/BDL/start [data dostępu: 25.02.2016].

Centralna Ewidencja i Informacja o Działalności Gospodarczej, https://prod.ceidg.gov.pl/ ceidg/ceidg.public.ui/search [data dostępu: 25.02.2016]. 